\title{
STUDI TENTANG POLA ASUH ORANG TUA TERHADAP PERILAKU HIDUP BERSIH DAN SEHAT ANAK USIA 5 - 6 TAHUN
}

\author{
Retno Setyo Iswati, Supartini \\ Tenaga Pengajar Prodi DIII Kebidanan Universitas PGRI Adi Buana Surabaya
}

\begin{abstract}
ABSTRAK
Pola asuh adalah cara orang tua mendidik anak dan membesarkan anak yang dipengaruhi oleh banyak factor. Pola asuh yang diterapkan akan mempengaruhi perilaku dan pola tumbuh kembang anak. (Markum, 2007). Membentuk perilaku sehat anak dimulai sejak usia dini. Anak yang mendapatkan pesan kesehatan yang intens semenjak usia 0-6 tahun memiliki harapan lebih besar untuk berperilaku sehat di masa mendatang. (Adiwiryono, 2011). Tujuan penelitian adalah studi tentang pola asuh orang tua terhadap perilaku hidup bersih dan sehat anak usia 5 6 tahun di TK Dharma Wanita Gisik Cemandi, Kabupaten Sidoarjo. Dalam penelitian digunakan metode deskriptif , desain penelitian cross sectional dengan populasi seluruh ibu di TK Dharma Wanita Gisik Cemandi, Kabupaten Sidoarjo yang berjumlah 40 responden(B2) Tahun 2013. Pengambilan sampel dengan total sampling dan instrument penelitian yaitu kuesioner. Analisis menggunakan persentase. Hasil penelitian diperoleh data bahwa sebagian besar responden menerapkan pola asuh penuntut $(42,5 \%)$ dan pola asuh tidak konsisten $(22,5 \%)$ sedangkan anak yang menerapkan perilaku hidup bersih dan sehat sebagian besar secara mandiri (50\%) sedangkan secara tidak konsisten sebesar $40 \%$. Dari hasil penelitian dapat disimpulkan bahwa pola asuh orang tua yang diterapkan mempengaruhi anak dalam berperilaku hidup bersih dan sehat.
\end{abstract}

Kata kunci : Pola Asuh, Perilaku Hidup Bersih dan Sehat

\section{PENDAHULUAN}

Pola asuh adalah cara orang tua mendidik anak dan membesarkan anak yang dipengaruhi oleh banyak faktor, antara lain faktor budaya, agama, kebiasaan dan kepercayaan, serta kepribadian oang tua (orang tua sendiri atau orang yang mengasuh anak). Macam - macam pola asuh yang biasa diterapkan antara lain pelindung, penuntut, dominan, pemanja, permisif, rejektif, pengkritik, tidak konsisten. Pola asuh pelindung membentuk anak menjadi penakut, tidak percaya diri, merasa khawatir, ragu, tidak mandiri, dan bila anak berontak akan melakukan semua larangan orang tua. Pola asuh penuntut bila anak gagal memenuhi tuntutan orang tua anak akan mengalami frustasi diikuti rasa bersalah dan dosa serta bila anak berontak maka akan sengaja menggagalkan diri (Markum, 2007).

Perbedaan sifat dan perilaku anak menimbulkan respon orang tua yang berbeda sehingga dapat dikatakan bahwa pengaruh anak terhadap orang tua mempunyai peran yang sama pentingnya dengan pengaruh orang tua terhadap anak. Keadaan perilaku akan mempengaruhi pola tumbuh kembang, perilaku yang sudah tertanam pada masa anak akan terbawa dalam masa kehidupan selanjutnya. Perubahan perilaku dan bentuk perilaku yang terjadi akibat pengaruh berbagai faktor lingkungan yang akan mempunyai dampak luas terhadap sosialisasi dan disiplin anak (Markum, 2007).

Membentuk perilaku sehat anak dimulai sejak usia dini. Anak yang mendapatkan pesan kesehatan yang intens semenjak usia 0-6 tahun memiliki harapan lebih besar untuk berperilaku sehat di masa mendatang. Sebaliknya anak yang tidak mendapatkan pesan kesehatan yang tidak intens maka perilaku sehat sulit terbentuk. Pendidikan kesehatan pada usia ini adalah peletak dasar bagi pendidikan kesehatan selanjutnya 
Rumusan masalah adalah bagaimanakah pengaruh pola asuh orang tua terhadap perilaku hidup bersih dan sehat anak usia 5 - 6 tahun di TK Dharma Wanita Gisik Cemandi, Kabupaten Sidoarjo? sedangkan tujuan penelitian adalah 1) Mengidentifikasi pola asuh orang tua. 2) Mengidentifikasi perilaku hidup bersih dan sehat anak usia $5-6$ tahun. 3) Menganalisis pengaruh pola asuh orang tua terhadap perilaku hidup bersih dan sehat anak usia $5-6$ tahun

\section{KAJIAN LITERATUR PENGEMBANGAN HIPOTESIS}

DAN

Pola asuh adalah cara orang tua mendidik anak dan membesarkan anak yang dipengaruhi oleh banyak faktor, antara lain faktor budaya, agama, kebiasaan dan kepercayaan, serta kepribadian oang tua (orang tua sendiri atau orang yang mengasuh anak) (Markum, 2007).

Menurut Markum (2007) bahwa macam pola pengasuhan yaitu :

1. Pola asuh pelindung

Pola asuh pelindung anak diperlakukan dengan penuh kekhawatiran, sering dilarang, dan terlalu dilindungi akan cenderung tumbuh menjadi penakut, tidak mempunyai kepercayaan diri, sering merasa khawatir dan ragu, tidak bisa mandiri.

2. Pola asuh penuntut

Pola asuh penuntut anak akan mendidik secara ambisius dengan tuntutan yang tinggi, menjadi tidak realistis. Bila anak gagal akan mengalami frustasi diikuti rasa bersalah dan dosa.

3. Pola asuh dominan

Orang tua terlalu dominan sehingga anak yang terlalu dikuasai cenderung tumbuh menjadi penakut, penurut, tidak mempunyai inisiatif, dan selalu takut berbuat salah. la tidak mempunyai kepercayaan diri dan selalu ragu bertindak.

4. Pola asuh pemanja

Anak yang terlalu dimanja cenderung untuk menjadi anak egois, tidak tahan frustasi, ingin selalu dapat perhatian dari lingkungan, banyak menuntut, mudah putus asa, dan tidak mempunyai daya juang untuk mencapai sesuatu. la kurang mempunyai rasa tanggung jawab dan cenderung untuk menggantungkan diri pada orang lain.

5. Pola asuh pengkritik

Anak yang terus menerus dikritik dan disorot semua kesalahannya merasa serba canggung, tidak mempunyai kepercayaan diri, merasa rendah diri, dan lama - kelamaan akan kehilangan inisiatif dan menjadi pasif. Sebagian anak akan berontak dan sengaja melakukan segala hal yang tidak disukai orang tuanya

6. Pola asuh yang tidak konsisten

Anak yang dididik dengan cara tidak konsisten akan merasa bingung mengenai nilai dan norma yang dianggap baik dan buruk, atau benar dan salah dalam masyarakat. la menjadi serba ragu dan bingung serta tidak mempunyai kepercayaan diri.

PHBS adalah semua perilaku kesehatan yang dilakukan atas kesadaran sehingga anggota keluarga atau keluarga dapat menolong dirinya sendiri di bidang kesehatan, dan berperan aktif dalam kegiatan-kegiatan kesehatan di masyarakat (Linda, dkk, 2010) . Indikator PHBS untuk anak usia dini masih merujuk pada PHBS Sekolah.

\section{METODE PENELITIAN}

Dalam penelitian digunakan metode deskriptif , desain penelitian cross sectional dengan populasi seluruh ibu di TK Dharma Wanita Gisik Cemandi, Kabupaten Sidoarjo yang berjumlah 40 responden (B2) Tahun 2013. Pengambilan sampel dengan total sampling dan instrument penelitian yaitu kuesioner untuk mengetahui pola asuh orangtua dan perilaku hidup bersih dan sehat anak Data yang dikumpulkan oleh peneliti berupa data karakteristik ibu (pendidikan dan pekerjaan). pola asuh orangtua dan perilaku hidup bersih dan sehat anak. Analisis menggunakan persentase. 


\section{HASIL DAN PEMBAHASAN}

Karakteristik ibu yang menjadi responden adalah : 1) tingkat pendidikan ibu paling banyak adalah menengah sejumlah 27 orang $(67,5 \%), 2)$ sebagian besar adalah ibu tidak bekerja sejumlah 33 orang $(82,5 \%)$.

Tabel 1. Distribusi Pola Asuh Orang Tua

\begin{tabular}{lcc}
\hline Pola Asuh & Frekuensi & Persentase \\
\hline Pelindung & 12 & 30 \\
Penuntut & 17 & 42,5 \\
Dominan & 1 & 2,5 \\
Pemanja & 0 & 0 \\
Pengkritik & 1 & 2,5 \\
Tidak Konsisten & 9 & 22,5 \\
\hline Jumlah & 40 & 100 \\
\hline
\end{tabular}

Dari tabel diatas menunjukkan bahwa sebagian besar (42,5\%) pola asuh responden terhadap anaknya berkategori penuntut dan tidak ada yang menerapkan pola asuh pemanja.

Tabel 2 : Distribusi Perilaku Hidup Bersih dan Sehat Anak Usia 5 - 6 Tahun

\begin{tabular}{lcc}
\hline Perilaku & Frekuensi & Persentase \\
\hline Mandiri & 20 & 50 \\
Kurang Mandiri & 4 & 10 \\
Tidak Mandiri & 0 & 0 \\
Tidak Konsisten & 16 & 40 \\
\hline Jumlah & 40 & 100 \\
\hline
\end{tabular}

Dari tabel dapat dilihat bahwa perilaku hidup bersih dan sehat anak usia 5 - 6 tahun sebesar (50\%) berkategori mandiri dan tidak ada yang berkategori tidak mandiri Tabel 3 : Tabulasi Silang Pola Asuh Orang Tua Terhadap Perilaku Hidup Bersih dan Sehat Anak Usia 5 - 6 Tahun

\begin{tabular}{|l|c|c|c|c|c|c|c|c|c|c|}
\hline \multirow{2}{*}{ Pola Asuh } & \multicolumn{8}{|c|}{ Perilaku Hidup Bersih Dan Sehat } & \multicolumn{2}{|c|}{} \\
\cline { 2 - 12 } & \multicolumn{2}{|c|}{ Mandiri } & \multicolumn{2}{|c|}{ Kurang Mandiri } & \multicolumn{2}{|c|}{ Tidak Mandiri } & \multicolumn{2}{|c|}{ Tidak Konsisten } & \multicolumn{2}{|c|}{} \\
\cline { 2 - 12 } & $\Sigma$ & $\%$ & $\Sigma$ & $\%$ & $\Sigma$ & $\%$ & $\Sigma$ & $\%$ & $\Sigma$ & $\%$ \\
\hline Pelindung & 6 & 50 & 1 & 8,33 & 0 & 0 & 5 & 41,67 & 12 & 100 \\
\hline Penuntut & 10 & 58,82 & 1 & 5,89 & 0 & 0 & 6 & 35,29 & 17 & 100 \\
\hline Dominan & 0 & 0 & 1 & 100 & 0 & 0 & 0 & 0 & 1 & 100 \\
\hline Pemanja & 0 & 0 & 0 & 0 & 0 & 0 & 0 & 0 & 0 & 100 \\
\hline Pengkritik & 1 & 100 & 0 & 0 & 0 & 0 & 0 & 0 & 1 & 100 \\
\hline $\begin{array}{l}\text { Tidak } \\
\text { Konsisten }\end{array}$ & 3 & 33,33 & 1 & 11,11 & 0 & 0 & 5 & 55,56 & 9 & 100 \\
\hline & 20 & & 4 & & 0 & & 16 & & 40 & \\
\hline
\end{tabular}

Dari tabel dapat dilihat bahwa pada penerapan pola asuh pelindung sejumlah 12 orang sebesar 50\% anaknya dapat menerapkan PHBS dengan mandiri, sedangkan pada pola asuh penuntut sejumlah 17 orang sebagian besar anaknya juga dapat menerapkan PHBS dengan mandiri (58,82\%). Pada penerapan pola asuh tidak konsisten sejumlah 9 orang, sebagian besar anaknya juga menerapkan HBS dengan tidak konsisten (55,56\%).

Pembahasan dalam hal ini sesuai dengan tujuan penelitian yaitu 1) Pola asuh yang diterapkan mendapatkan hasil bahwa dari 40 responden sebagian besar yaitu sejumlah 17 orang $(42,5 \%)$ menerapkan pola asuh penuntut. Pada pola asuh penuntut anak akan dididik secara ambisius dengan tuntutan yang tinggi, cenderung untuk mengambil alih nilai - nilai yang terlalu tinggi tersebut sehingga menjadi tidak realistis. 2) Perilaku hidup bersih dan sehat yang 
diterapkan anak sebagian besar (50\%) berkategori mandiri dan tidak ada yang berkategori tidak mandiri . Hal tersebut sesuai dengan teori yang menyatakan bahwa perilaku anak pada usia 5-6 tahun cenderung untuk meniru perilaku orang disekitarnya atau dalam lingkungan keluarga. Jika dalam lingkungan keluarganya perilaku hidup bersih dan sehatnya baik maka anak cenderung untuk menirunya untuk ikut berperilaku hidup bersih dan sehat tetapi hal ini dikaitkan dengan pendidikan dalam rumah atau pola asuh yang diterapkan oleh orang tua. Apabila orang tua konsisten dan tegas dalam menerapkan hidup bersih dan sehat maka anak dapat berperilaku hidup bersih dan sehat pula. 3) Hasil analisis menggunakan tabulasi silang antara pola asuh orang tua terhadap perilaku hidup bersih dan sehat anak dapat diketahui bahwa dari 40 responden terdapat 17 orang (42,5\%) yang menerapkan pola asuh penuntut. Pada anak dengan pola asuh penuntut didapatkan perilaku hidup bersih dan sehat dengan kategori mandiri sebesar $58,82 \%$, kategori tidak konsisten sebesar $35,29 \%$, kategori kurang mandiri sebesar $5,89 \%$ dan tidak ada yang berperilaku tidak mandiri. Anak yang diasuh dengan pola asuh yang tidak konsisten $(22,5 \%)$ menerapkan perilaku hidup bersih dan sehat dengan kategori tidak konsisten $55,56 \%$, kategori mandiri 33,33\%, kategori kurang mandiri $11,11 \%$ dan tidak ada yang berkategori tidak mandiri. Penerapan pola asuh yang memberikan batas-batas yang tegas dalam perilaku hidup bersih dan sehat maka anak dapat berperilaku hidup bersih dan sehat secara mandiri. Perilaku anak pada usia 5-6 tahun cenderung untuk meniru perilaku orang disekitarnya atau dalam lingkungan keluarga. Apabila orang tua konsisten dan tegas dalam menerapkan hidup bersih dan sehat maka anak dapat berperilaku hidup bersih dan sehat pula, tetapi jika orangtua tidak konsisten dalam menerapkan hidup bersih dan sehat maka anakpun akan menerapkan perilaku hidup bersih dan sehat secara tidak konsisten pula. Pola asuh yang diterapkan orangtua akan mendasari anak untuk berperilaku dalam perkembangan selanjutnya

\section{KESIMPULAN}

Dari hasil penelitian dapat disimpulkan bahwa :

1. Pola asuh orang tua yang diterapkan pada anak usia 5-6 tahun di TK Dharma Wanita Gisik Cemandi, Kabupaten Sidoarjo sebagian besar adalah pola asuh penuntut.

2. Perilaku hidup bersih dan sehat pada anak usia 5 - 6 tahun di TK Dharma Wanita Gisik Cemandi, Kabupaten Sidoarjo sebagian besar adalah berkategori mandiri

3. Pola asuh orang tua mempengaruhi perilaku hidup bersih dan sehat anak usia $5-6$ tahun, pada anak dengan pola asuh penuntut sebagian besar berperilaku hidup bersih dan sehat dengan berkategori mandiri sedangkan pada pola asuh tidak konsisten maka anak berperilaku hidup bersih dan sehat secara tidak konsisten juga.

Berdasarkan hasil penelitian diharapkan orang tua perlu mengetahui dan memahami bahwa untuk menerapkan pola asuh yang sesuai dengan tahapan atau usia anak, maka orang tua hendaknya banyak membaca buku dan mencari informasi tentang kebutuhan dan penenerapan perilaku hidup bersih dan sehat dalam tahapan anak agar anak dapat mencapai perilaku yang sesuai.

\section{DAFTAR PUSTAKA}

Adiwiryono, RM. (2011). Pesan Kesehatan Perilaku Hidup bersih dan Sehat (PHBS) Anak Usia Dini dalam Kurikulim Pendidikan Anak Usia Dini. Selasa Maret 2012. http://blog.uad.ac.id/meilanasapta/f iles/2011/12
Arikunto, S. (2010). Prosedur Penelitian Suatu Pendekatan Praktek. Jakarta: Rineka Cipta.

Chalke. (2010). Kiat-kiat Menjadi Ortu Teladan. Jogjakarta: Inspirasi Buku 
Utama (2010). Pedoman PHBS. Selasa Maret 2012. http://www.depkes.go.id.
Markum, A.H. (2007). Buku Ajar Kesehatan Anak. Jilid I. Jakarta: FKUI.

Edward. (2009). Perkembangan Anak dan Balita. Jakarta: Rineka Cipta

Harjaningrum, dkk. (2007). Peranan Orang Tua dan Praktisi dalam Membantu Tumbuh Kembang Anak Berbakat Melalui Pemahaman Teori dan Tren Pendidikan. Jakarta : Prenada Media Group.

Hidayat, AAA. (2007). Metode Penelitian Kebidanan Teknik Analisis Data. Jakarta : Salemba Medika

Hurlock, E.B. (2007). Perkembangan Anak. Jakarta: Erlangga.

Junaidi, W. (2010). Macam-macam Pola Asuh Orang Tua. Selasa Maret $2012 . \quad$ http://wawanjunaidi.blogspot.com/2010/02/

Linda, dkk. (2010). Praktik Perilaku Bersih dan Sehat (PHBS) pada Peserta Pendidikan Anak Usia Dini (PAUD) di Kec. Koja, Jakarta Utara Tahun 2010. Selasa Maret 2012. http://www.uhamka.ac.id/file/article 